\title{
Clinical Profile of Patients Admitted with Seizure Disorder in a Tertiary Care Hospital of Central Nepal
}

\author{
Isha Bhandari,' Kalpana Karmacharya Malla,' Pukar Ghimire, ${ }^{2}$ Bibek Bhandari' \\ 'Department of Pediatrics, ${ }^{2}$ Department of Internal Medicine, College of Medical Sciences, Chitwan, Nepal.
}

\section{ABSTRACT}

\section{Introduction}

Seizure is a common clinical condition and one of the commonest reasons of hospital admission in childern. This study aims to address the etiology and clinical characteristics of children with seizure.

\section{Methods}

This was a descriptive, cross-sectional, observational study in which children of age 1 month to 15 years presenting with seizure were included. The data was analyzed using SPSS 16.0.

\section{Results}

Out of 192 patients, $126(65.6 \%)$ were males and 66(65.6\%) were females with the ratio of 1.9:1. Distribution of events in different age groups were $16.1 \%(n=31)$ in group of 1 month to 1 years, $63 \%$ $(n=121)$ in group of 1 yrs to 5 years, $12.1 \%(n=24)$ in group of 5 years to 10 years and $8.3 \%(n=16)$ in children above 10 years. $70.3 \%$ had febrile seizure, with the highest incidence in age group of 1 to 5 years. Generalised tonic clonic seizure was seen in $94.3 \%$ and focal motor seizure in $5.7 \%$. No difference was seen in distribution of the type of seizure across different age groups $(\mathrm{p}=0.192)$. Presenting complaints were fever in $75.5 \%$, loss of consciousness in $26.0 \%$, vomiting in $25.0 \%$, headache in $23.4 \%$, altered sensorium in $8.3 \%$ and focal neurological deficits in $8.3 \%$. $33.9 \%$ of children had a family history of seizure. Causes of febrile seizures included upper respiratory tract infectionin $82.2 \%$, acutegastroenteritis in $12.6 \%$, urinary tractinfection in $3 \%$ and pneumonia in $2.2 \%$. Afebrile seizure was idiopathic in $38.6 \%$ and identifiable causes in the remaining were sequelae of birth asphyxia in $17.6 \%$, hypoglycemia in $8.8 \%$, neuronal migration defects and neurocysticercosis in $5.3 \%$. No relation was observed between the history of perinatal asphyxia and the age of onset of seizure $(\mathrm{p}=0.250)$. Of all the patients $57.8 \%$ were discharged without antiepileptic, $27.6 \%$ were treated with monotherapy whereas $14.5 \%$ required polytherapy to achieve seizure control. Conclusions

Seizure is a common problem in children, with the highest incidence in the age group of 1 to 5 years and febrile seizure is the most common type of seizure in children.

Keywords: children; genereralized epilepsy; febrile seizures.

Correspondence: Dr. Isha Bhandari, Department of Pediatrics College Of Medical Sciences, Chitwan, Nepal. Email: isha758@hotmail.com, Phone:+977-9841810937. 


\section{INTRODUCTION}

Seizure is a transient occurrence of signs and/or symptoms resulting from abnormal excessive or synchronous neuronal activity in the brain and is acommon cause of hospital admission with significant morbidity and mortality in children. Approximately $4-10 \%$ of children experience at least one episode of seizure in the first 16 years of life and about $1 \%$ of children land in emergency with the complaint of seizure. ${ }^{1}$

Incidence of seizure is highest in children less than 3 years, which then gradually decreases with increase in age. ${ }^{2}$ Most studies show higher incidence in males than in females., ${ }^{3,4}$ Febrile seizure is the most common type of acute seizure in children all around the globe.

Focused clinical history and examination is of immense help for identifying the cause of the seizure in pediatric patients as investigation and neuroimaging is of little help ${ }^{5}$. This study aims to study the epidemiology, presentation and other clinical characteristics in children with seizure.

\section{METHODS}

This study was a descriptive, cross-sectional study conducted at College of Medical Sciences Teaching Hospital (COMS-TH), a tertiary care referral hospital, over a period of 2 years from February 2018 to January 2020. We included 192 children who presented with seizure during the study period. Those who developed seizure during the course of hospital stay were not included in the study. The information on demographics, clinical presentation, examination findings, and neuroimaging were obtained.

Seizure type classification was done as per the International League Against Epilepsy (ILAE)2017.

A seizure is considered generalized in onset if it engages bilateral brain networks from onset and focal if it begins in one region or hemisphere. Generalized onset seizures can befurtherclassified into motor or nonmotor (absence) onset. Focal seizures are further subdivided into one) whether they are associated with impaired awareness and 2) whether they are associated with motor (tonic, clonic, atonic, or myoclonic activity) or nonmotor (behavior arrest, cognitive, emotional, sensory, or autonomic features) symptoms.

Febrile seizure is defined as " a seizure occurring in childhood after 1 month of age associated with a febrile illness not caused by CNS infection, without previous neonatal seizures or a previous unprovoked seizure, and not meeting the criteria for other acute symptomatic seizures" 6

Descriptive statistics was used for the analysis. Chi square test was used to test the significance. $\mathrm{P}$ value $<0.05$ was considered significant.

The data was analyzed using SPSS (Statistical Package for Social Sciences)for windows Version-16.0.

\section{RESULTS}

Out of 192 patients who presented with seizure, the mean age was $3.9 \pm 3.3$ years with the highest incidence $63 \%(n=121)$ in children of age group of $1 y r$ to 5years and the remaining distributed as $16.1 \%(n=31)$ in age group of 1 month to 1 years, $12.5 \%(n=24)$ in age group of 5 years to 10 years and $8.3 \%(n=16)$ in age group 10 years to 15 years. (Table 1)

\begin{tabular}{|c|l|l|}
\hline \multicolumn{3}{|c|}{ Table 1: Demographics of the patient } \\
\hline Characteristics & $\begin{array}{l}\text { Frequency } \\
\text { (N= 192) }\end{array}$ & Percentage \\
\hline Age (Mean \pm SD) & $\begin{array}{l}3.9 \pm 3.3 \\
\text { years }\end{array}$ & \\
\hline Age groups & & $16.1 \%$ \\
1 month - 1 year & 31 & $63.0 \%$ \\
$1-5$ year & 121 & $12.1 \%$ \\
$5-10$ years & 24 & $8.3 \%$ \\
$10-15$ years & 16 & \\
\hline Gender (M:F= 1.9:1) & 126 & $65.6 \%$ \\
Male & 66 & $34.4 \%$ \\
Female & & \\
Religion & 182 & $94.8 \%$ \\
Hindu & 6 & $3.1 \%$ \\
Buddhist & 4 & $2.1 \%$ \\
\hline
\end{tabular}


There were $65.6 \% \quad(n=126)$ males and $34.4 \%$ $(\mathrm{n}=66)$ females with male to female ratio of 1.9:1. Seizure was more common in males below 10 years with most frequent in males of age in between 1 to 5 years. (Figure 1) Majority of the patients were hindus (94.8\%). (Table 1)

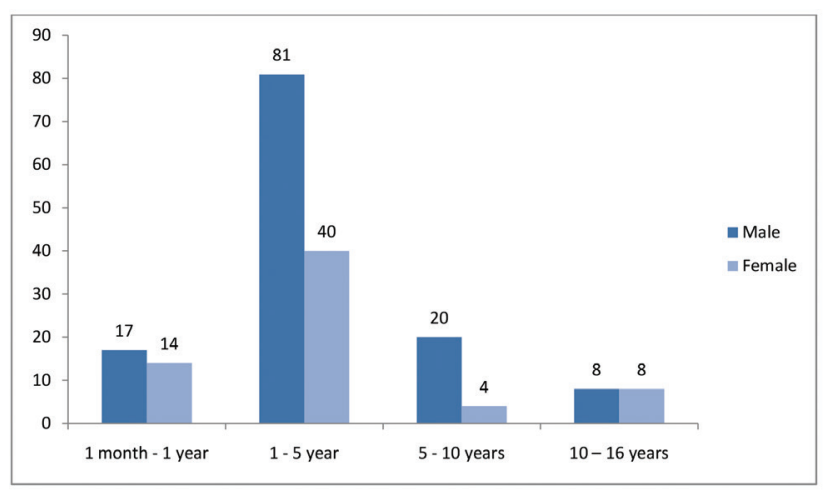

Figure 1. Gender distribution across different age groups

The symptoms associated in children with seizure in decreasing order were fever in $75.5 \%$, loss of consciousness in $26.0 \%$, vomiting in $25.0 \%$, headache in $23.4 \%$ and altered sensorium in $8.3 \%$. Focal neurological deficits were found only in $8.3 \%$ of patients on examination. (Table 2)

\begin{tabular}{|c|c|c|}
\hline Characteristics & $\begin{array}{l}\text { Frequency } \\
(\mathrm{N}=192)\end{array}$ & Percentage \\
\hline \multicolumn{3}{|l|}{ Symptoms at presentation } \\
\hline Fever & 143 & $75.5 \%$ \\
\hline Loss of consciousness & 50 & $26.0 \%$ \\
\hline Vomiting & 48 & $25.0 \%$ \\
\hline Headache & 45 & $23.4 \%$ \\
\hline Altered sensorium & 16 & $8.3 \%$ \\
\hline $\begin{array}{l}\text { Focal neurological deficit } \\
\text { at examination }\end{array}$ & 16 & $8.3 \%$ \\
\hline
\end{tabular}

Family history of seizures was present in 33.9\% $(\mathrm{n}=65)$. Febrile seizure was more frequent $(70.3 \%)$ as compared to afebrile seizure (29.7\%) (Table 3)
Table 3. Characteristics of seizure

\begin{tabular}{|c|l|l|}
\hline Characteristics & $\begin{array}{l}\text { Frequency } \\
(\mathbf{N}=192)\end{array}$ & Percentage \\
\hline $\begin{array}{c}\text { Family history of seizure } \\
\text { Present }\end{array}$ & 65 & 33.9 \\
Absent & 127 & 66.1 \\
\hline $\begin{array}{c}\text { Type of seizure } \\
\text { Febrile }\end{array}$ & 135 & $70.3 \%$ \\
Afebrile & 57 & $29.7 \%$ \\
\hline Seizure semiology & 181 & $94.3 \%$ \\
GTCS & 11 & $5.7 \%$ \\
Focal onset, Motor & \\
\hline
\end{tabular}

GTCS, 94.3\% ( $n=181)$, was the most frequent type of seizure found. No differences was found in the distribution of the type of seizures (GTCS and Focal) across different age groups. $(p=0.192)$ (Figure 2)

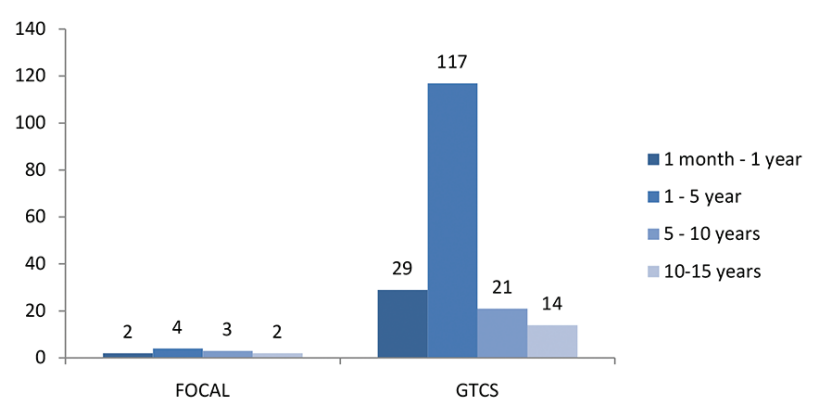

Figure 2. Seizure distribution as per age group

There was no difference between the distribution of seizure (GTCS and Focal) in regard to gender. $(p=0.609)$ (Figure 3)

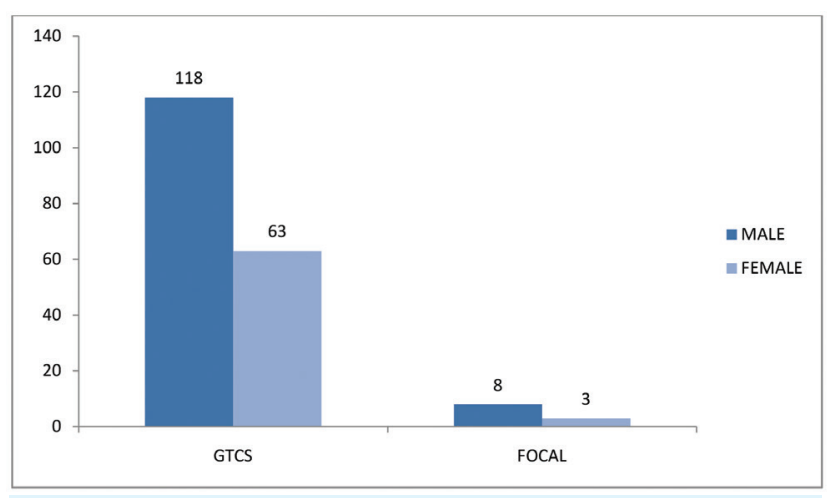

Figure 3. Distribution of seizure in regard to gender 
Common causes of febrile seizures were URTI in $82.2 \%$, AGE in $12.6 \%$,UTI in $3 \%$ and pneumonia in $2.2 \%$. Among children with afebrile seizure $17.6 \%$ had structural defects secondary to birth asphyxia as the cause of seizure, $5.3 \%$ had neuronal migrational defects and $5.3 \%$ had each of NCC and hypoglycemia. The cause was unknown in $38.6 \%$ of the cases. (Table 4 )

\begin{tabular}{|c|c|c|}
\hline Characteristics & Frequency & Percentage \\
\hline \multicolumn{3}{|l|}{$\begin{array}{l}\text { Causes of febrile seizure } \\
(N=135)\end{array}$} \\
\hline URTI & 111 & $82.2 \%$ \\
\hline AGE & 17 & $12.6 \%$ \\
\hline UTI & 4 & $3.0 \%$ \\
\hline Pneumonia & 3 & $2.2 \%$ \\
\hline \multicolumn{3}{|l|}{$\begin{array}{l}\text { Causes of Afebrile } \\
\text { seizure }(N=57)\end{array}$} \\
\hline Birth asphyxia & 10 & $17.6 \%$ \\
\hline Hypogylcemia & 5 & $8.8 \%$ \\
\hline CNS malformation & 3 & $5.3 \%$ \\
\hline NCC & 3 & $5.3 \%$ \\
\hline Unknown & 22 & $38.6 \%$ \\
\hline
\end{tabular}

Out of 192 patients neuro imaging was done in 45 patients. 26 had normal findings and of the remaining, $17.6 \%$ had structural abnormalities secondary to birth asphyxia, 5.3\% had neuronal migrational defects and $5.3 \%$ had NCC.

Of these patients, $57.8 \%$ were discharged without any antiepileptics, whereas $27.6 \%$ were treated with a single antiepileptic drug, whereas $14.5 \%$ required more than one antiepileptic drugs to have the seizure controlled.

\section{DISCUSSION}

This was a hospital based observational study of children who had seizure in COMSTH from 20182020.The aim was to study the demographics, seizure type and clinical characteristics of seizure in children admitted to a tertiary care hospital in
Central Nepal.

In our study the prevalence of seizure was seen higher in younger age group (1 yr -5yrs) as compared to older ones and $\mathrm{M}: \mathrm{F}$ ratio was 1.9:1which was similar to what was observed in few other studies. ${ }^{7,8}$

Children of younger age group are more susceptible to get infected with viral infections, otitis media, respiratory tract infection that results in high temperature and there are animal model studies which suggest the central role of inflammatory mediators like IL-1 that could cause an increase in neuronal stimulation and the onset of febrile seizure..$^{9,10}$

Thus febrile seizure is the commonest cause of seizure in children all around the world. This fact has been reported in other studies. ${ }^{11}$ We too found febrile seizure to be the commoner than afebrile seizure.

Similar to the finding in our study, GTCS has always been reported as the commonest type of seizure. ${ }^{12-15}$

Positive family history is one of the important risk factor for seizure in children. Similar to what was noted by Waruiru e tal., we found that $33.9 \%$ of our patients had a family history of seizure. ${ }^{16}$

In our study URTI was the most common cause of febrile seizure which was similar to the finding noted by Abuekteish F etal. ${ }^{17}$

There are studies showing that about $9-33 \%$ of babies having birth asphyxia develop epilepsy in later life ${ }^{18,19}$ A study by Bergamasco et al reported that the risk of having epilepsy is five times higher in those babies who suffered birth asphyxia as compared to those who had normal transistion. ${ }^{20}$

There are rapid increases in synaptic potency that appear to mimic long-term potentiation, and this pathologic activation may contribute to enhanced epileptogenesis ${ }^{21}$ 
In a study done by Annegeers JF et al perinatal asphyxia was observed as cause of seizure in about $55 \%$ of the cases. ${ }^{22}$ We also found that structural defects secondary to hypoxic insult remains the most common cause of afebrile seizure.

Metabolic derangement, commonly hypoglycemia, is also a common cause of provoked seizure.. ${ }^{23}$ Our study population also had hypoglycemia as second most common cause of afebrile seizure..

As per American Association of Pediatrics (AAP) guidelines, diagnosis of febrile seizure is mainly on clinical grounds and requires uncovering the medical etiology in first episode of febrile seizure. Lumbar puncture in febrile seizure is warranted only if there are others clinical signs and symptoms suggesting CNS infections. ${ }^{24}$

Similarly, risk and benefit of routine neuroimaging in all children admitted with acute episode of seizure is still a matter of debate as discussed in studies. ${ }^{15,25}$ In our study $23.4 \%$ of patient had done neuroimaging. The most common abnormality noted was structural changes secondary to hypoxic insult, in $22.2 \%$ which was also similar in the study by Poudel et al. ${ }^{15.26}$

Commonest antiepileptic which we used was sodium valporate as it has broad-spectrum efficacy and is the drug of choice in focal and generalized epilepsy and has been used as first choice by other authors as well. ${ }^{27}$

\section{CONCLUSION}

Seizure is one of the commonest presentations in hospital which bears high impact on quality of life of the children as well as the family. Febrile seizure carries the higher incidence in younger children.Laboratory investigations and neuroimaging is still matter of debate in every case of seizure.Thus descriptive studies involving many domains are to be conducted for proper understanding of the real burden of seizure.

\section{ACKNOWLEDGEMENTS}

We express our sincere gratitude to all the faculties of Department of Pediatrics and Department of Medicine as well as all the technical staff of College of Medical Sciences and Teaching Hospital.

\section{REFERENCES}

1. Roth HL, Drislane FW. Seizures. Neurol Clin 1998;16:257-84.

2. Friedman MJ, Sharieff GQ. Seizures in children. Pediatric clinics of North America. 2006 Apr;53(2):257-77. PubMed PMID: 16574525. Epub 2006/04/01. eng. [DOI]

3. Russ SA, Larson K, Halfon N. A national profile of childhood epilepsy and seizure disorder. Pediatrics. 2012 Feb;129(2):25664.[PUBMED]

4. Aaberg KM, Gunnes N, Bakken IJ, Lund Søraas C, Berntsen A, Magnus P, et al. Incidence and Prevalence of Childhood Epilepsy: A Nationwide Cohort Study. Pediatrics. 2017 May;139(5). [PUBMED]

5. Graves RC, Oehler K, Tingle LE. Febrile seizures: risks, evaluation, and prognosis. American family physician. 2012 Jan 15;85(2):149-53.[PUBMED]

6. Guidelines for epidemiologic studies on epilepsy. Commission on Epidemiology 
and Prognosis, International League Against Epilepsy. Epilepsia. 1993 JulAug;34(4):592-6.[PUBMED]

7. Martindale JL, Goldstein JN, Pallin DJ. Emergency department seizure epidemiology. Emergency Medicine Clinics. 2011;29(1):15-27.[PUBMED]

8. Chen CY, Chang YJ, Wu HP. Newonset seizures in pediatric emergency. Pediatrics and neonatology. 2010 Apr;51(2):103-11.[PUBMED]

9. Haspolat S, Mihçi E, Coşkun M, Gümüslü S, Ozben T, Yeğin O. Interleukin-1beta, tumor necrosis factor-alpha, and nitrite levels in febrile seizures. Journal of child neurology. 2002 Oct;17(10):749-51. [PUBMED]

10. Chiu SS, Tse CY, Lau YL, Peiris M. Influenza A infection is an important cause of febrile seizures. Pediatrics. 2001 Oct;108(4):E63.[PUBMED]

11. Ojha AR, Ojha UR. Clinico-etiological profile of children with seizures admitted in a tertiary centre. Journal of Kathmandu Medical College. 2015;4(2):55-8.[DOI]

12. Idro R, Gwer S, Kahindi M, Gatakaa $\mathrm{H}$, Kazungu T, Ndiritu M, et al. The incidence, aetiology and outcome of acute seizures in children admitted to a rural Kenyan district hospital. BMC pediatrics. 2008;8(1):1-11.[PUBMED]

13. Huang CC, Chang YC, Wang ST. Acute symptomatic seizure disorders in young children-a population study in southern Taiwan. Epilepsia. 1998;39(9):960-4. [PUBMED]

14. Saravanan S. Profile of children admitted with seizures in a tertiary care hospital in
South India. IOSR Journal of Dental and Medical Sciences. 2013;11(4):56-61.

15. Chen C-Y, Chang Y-J, Wu H-P. New-onset seizures in pediatric emergency. Pediatrics \& Neonatology. 2010;51(2):103-11.[PUBMED]

16. Waruiru C, Appleton R. Febrile seizures: an update. Archives of disease in childhood. 2004 Aug;89(8):751-6. PubMed PMID: 15269077.[PUBMED]

17. Abuekteish F, Daoud AS, al-Sheyyab M, Nou'man M. Demographic characteristics and risk factors of first febrile seizures: a Jordanian experience. Tropical doctor. 2000 Jan;30(1):25-7. [PUBMED]

18. Pisani F, Orsini M, Braibanti S, Copioli C, Sisti L, Turco EC. Development of epilepsy in newborns with moderate hypoxic-ischemic encephalopathy and neonatal seizures. Brain \& development. 2009 Jan;31(1):64-8.[PUBMED]

19. van Kooij BJ, van Handel $M$, Nievelstein RA, Groenendaal F, Jongmans MJ, de Vries LS. Serial MRI and neurodevelopmental outcome in 9- to 10-year-old children with neonatal encephalopathy. The Journal of pediatrics. 2010 Aug;157(2):221-7 e2.[PUBMED]

20. Bergamasco B, Benna P, Ferrero P, Gavinelli R. Neonatal hypoxia and epileptic risk: a clinical prospective study. Epilepsia. 1984 Apr;25(2):131-6. [PUBMED]

21. Rakhade SN, Zhou C, Aujla PK, Fishman R, Sucher NJ, Jensen FE. Early alterations of AMPA receptors mediate synaptic 
potentiation induced by neonatal seizures. The Journal of neuroscience : the official journal of the Society for Neuroscience. 2008 Aug 6;28(32):797990.[PUBMED]

22. Annegers JF, Hauser WA, Lee JR, Rocca WA. Incidence of acute symptomatic seizures in Rochester, Minnesota, 19351984. Epilepsia. 1995 Apr;36(4):327-33. [PUBMED]

23. Mountz JM, Patterson CM, Tamber MS. Pediatric Epilepsy: Neurology, Functional Imaging, and Neurosurgery. Seminars in nuclear medicine. 2017 Mar;47(2):170-87.[PUBMED]

24. Michelson KA, Lyons TW, Johnson KB, Nigrovic LE, Harper MB, Kimia AA.
Utility of Lumbar Puncture in Children Presenting With Status Epilepticus. Pediatric emergency care. 2017 Aug;33(8):544-7.[PUBMED]

25. Goldstein JL. Evaluating new onset of seizures in children. Pediatric annals. 2004 Jun;33(6):368-74.[PUBMED]

26. Poudel P, Parakh P, Mehta K. Clinical profile, aetiology and outcome of afebrile seizures in children. JNMA; Journal of the Nepal Medical Association. 2013 Jan-Mar;52(189):260-6.[PUBMED]

27. Rosati A, De Masi S, Guerrini R. Antiepileptic Drug Treatment in Children with Epilepsy. CNSDrugs. 2015 2015/10/01;29(10):847-63.[PUBMED]

Citation: Bhandari I, Malla K, Ghimire P, Bhandari B. Clinical Profile of Patients Admitted with Seizure Disorder in a Tertiary Care Hospital of Central Nepal. JCMS Nepal. 2021 ; 17(2); $129-35$. 